\title{
PENGARUH KEKASARAN AMPELAS TERHADAP KEKASARAN PERMUKAAN BAHAN ALUMINIUM, KAYU JATI, DAN MAHONI
}

\author{
Sri Harmanto \\ Jurusan Teknik Mesin, Politeknik Negeri Semarang \\ Jl. Prof. Soedarto, SH, Tembalang, Semarang 50275 \\ E-mail: sri.harmanto@yahoo.co.id
}

\begin{abstract}
Abstrak
Proses pengampelasan menjadi permasalahan utama yang menghambat proses produksi kerajinan di UKM pengecoran aluminium dan mainan anak dari bahan kayu jati dan mahoni sehingga tidak bisa memenuhi pesanan sesuai target. Tujuan dari penelitian ini adalah untuk meneliti pengaruh kekasaran ampelas terhadap kekasaran permukaan pada bahan aluminium, kayu jati, dan kayu mahoni. Metode yang digunakan pada penelitian ini adalah : Studi literatur, Pemilihan bahan dan peralatan, Modifikasi mesin ampelas sabuk (Belt Sanders), Pembuatan spesimen, Proses pengampelasan, Pengujian kekasaran, Analisa data, dan Kesimpulan. Parameter yang digunakan adalah nomor ampelas (Mesh), dengan variabel : 60, 100, 150, 180, dan 240. Hasil dari penelitian ini adalah semakin tinggi nomor ampelas, semakin halus permukaan bahan. Pada aluminium dengan ampelas no. 60, kekasaran rata-ratanya

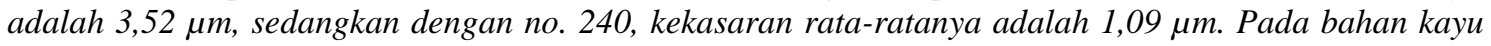
jati dengan ampelas no 60 dan no. 240, kekasaran yang diperoleh adalah 10,20 $\mu \mathrm{m}$ dan 3,67 $\mu \mathrm{m}$, sedangkan pada bahan kayu mahoni dengan ampelas no 60 dan no. 240, kekasaran yang diperoleh

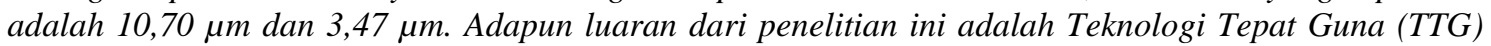
berupa mesin ampelas sabuk dan data-data hasil penelitian yang dipublikasikan dalam bentuk Jurnal ilmiah ber-ISSSN.
\end{abstract}

Kata Kunci : "Kekasaran ampelas", "Kekasaran permukaan”, "Aluminium, Jati, Mahoni"

\section{Pendahuluan}

Kerajinan coran aluminium di Desa Sejomulyo, Juwana, Pati dan mainan anak dari bahan kayu di Desa Kemiri Kecamatan Mojosongo Kabupaten Boyolali Provinsi Jawa Tengah ini telah banyak dipasarkan di kota-kota besar seperti Semarang, Surabaya, Yogyakarta, Bandung, Jakarta, dan Bali sebagai daerah tujuan wisata, baik wisatawan dalam negeri maupun manca negara. Bahkan secara rutin sudah diekspor ke Jepang, Amerika, dan beberapa Negara di Eropa. Produk-produk yang dihasilkan oleh UKM "BUDI JAYA LOGAM" antara lain : topeng, asbak, buah-buahan, dan binatang. Sedangkan mainan anak-anak dari bahan kayu, seperti : mobil-mobilan, bus, bolduser, pesawat terbang, becak, dan lain-lain.

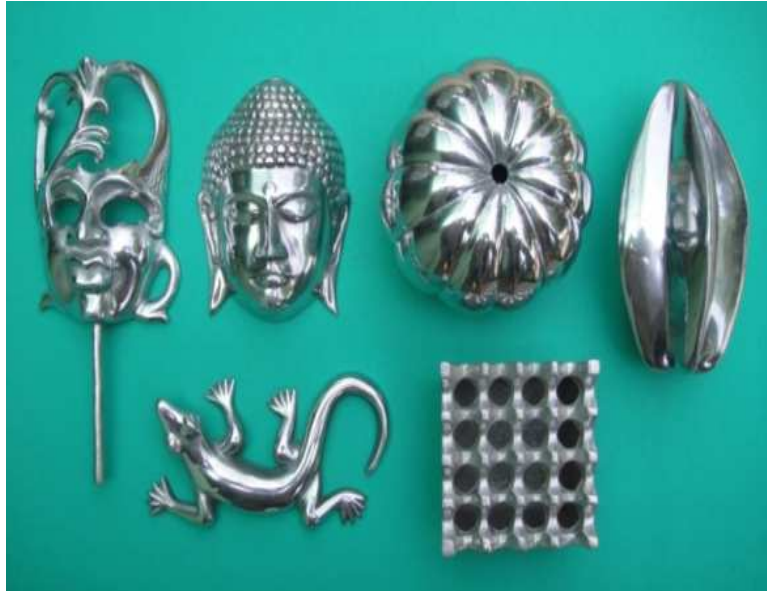

Gambar 1. Kerajinan coran aluminium

(Sumber:Penel. Terapan Pratama 2018)

Sedangkan produk-produk yang dihasilkan UKM "TETAP JAYA ART" di Desa Kemiri Kecamatan Mojosongo Kabupaten Boyolali dapat dilihat seperti pada Gambar 2 di bawah ini. 


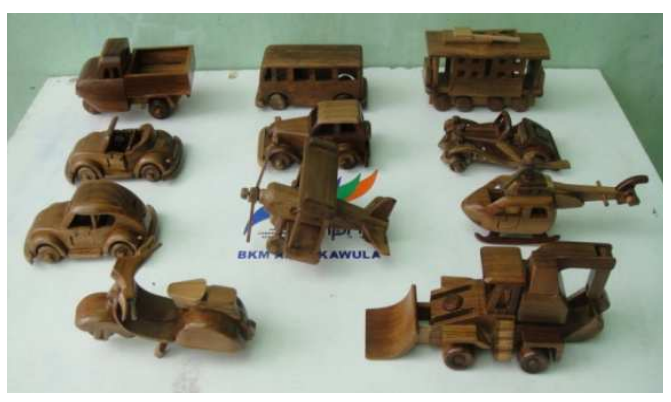

Gambar 2. Produk kerajinan kayu (Sumber:Penel. Terapan Pratama 2018)

Proses pengerjaan finishing, khususnya pengampelasan menjadi permasalahan utama yang menghambat proses produksi sehingga tidak bisa memenuhi pesanan sesuai target. Pengampelasan dengan menggunakan tangan selain membutuhkan waktu lama juga menghasilkan kekasaran yang tidak merata. Menurut beberapa literatur untuk meningkatkan kualitas dan kuantitas hasil pengampelasan bisa menggunakan mesin pengampelas dengan kekasaran ampelas yang tepat.

Tujuan dari penelitian ini adalah untuk meneliti pengaruh kekasaran ampelas terhadap kekasaran permukaan pada bahan aluminium, kayu jati, dan kayu mahoni. Hasil yang diharapkan dari penelitian ini adalah kekasaran bahan bisa mencapai $1,0 \mu \mathrm{m}$.

\subsection{Proses Pengampelasan}

Sebagai proses permesinan, proses pengamplasan akan mempengaruhi kualitas produk kerajinan. Efisiensi pengamplasan sabuk abrasif dapat dievaluasi dengan tingkat pelepasan material, sedangkan mutu/kualitas permukaan dapat dievaluasi dengan kekasaran permukaan Ra. Namun, keduanya akan dipengaruhi oleh banyak faktor, seperti sifat bahan, granularitas sabuk abrasif, arah pengamplasan, tekanan dan lain sebagainya. Menurut Taylor dkk. (1999) mempelajari hubungan antara variabel input dan tingkat removal material sangat menentukan kekasaran permukaan. Berkenaan dengan ukuran pasir kasar dan semua spesies, silikon karbida menghasilkan permukaan yang lebih baik daripada aluminium oksida. Menurut Magoss dan Sitkei (2001), kualitas permukaan akan dipengaruhi oleh beberapa faktor baik dari sifat bahan maupun proses permesinan. Sifat bahan meliputi butiran, kerapatan, kadar air dan lainnya. Menurut Saloni dkk. (2005), tingkat pelepasan material dapat berubah dengan variasi tekanan, tipe abrasif, granularitas dan kecepatan pengampelasan. Dalam kebanyakan kasus, kecepatan pengampelasan yang lebih tinggi bisa menghasilkan permukaan yang lebih baik. Gambar 3 menunjukkan variasi kekasaran permukaan bahan yang diampelas dengan sabuk abrasif grit 60 dan 100, baik dalam arah longitudinal dan melintang. Dapat dicatat bahwa kekasaran permukaan pengampelasan longitudinal lebih tinggi daripada pengampelasan melintang. Pengamatan serupa telah diteliti oleh de Moura dkk. (2011), mereka menegaskan bahwa kekasaran permukaan jelas lebih tinggi secara tegak lurus ke arah penggerak sabuk abrasif dari pada sejajar. Masing-masing butir akan memberikan kedalaman yang lebih kecil, sehingga menghasilkan hasil akhir yang lebih baik.
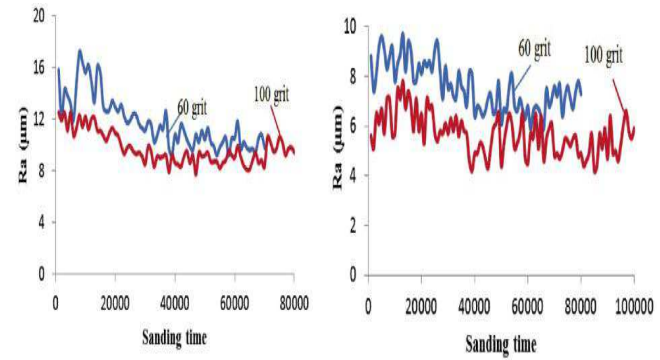

Gambar 3. Pengaruh kekasaran permukaan
dengan grit 60 dan 100 (Saloni dkk. (2005)

Hal ini terutama dihasilkan dari sifat spesimen yang berbeda itu sendiri. Serat kayu bahan tampak lebih tidak beraturan dan 
lebih kecil dari bahan keras. Dalam proses pengampelasan, serat bahan lunak tidak dapat terputus sepenuhnya. Sedangkan bahan keras memiliki kekasaran yang relatif lebih tinggi sehingga bekas pengampelasan di permukaan tidak terlihat. Selain itu, berdasarkan Aguilera (2011), kekasaran permukaan yang dihasilkan pada kondisi pemesinan yang berbeda mengikuti hubungan linier.

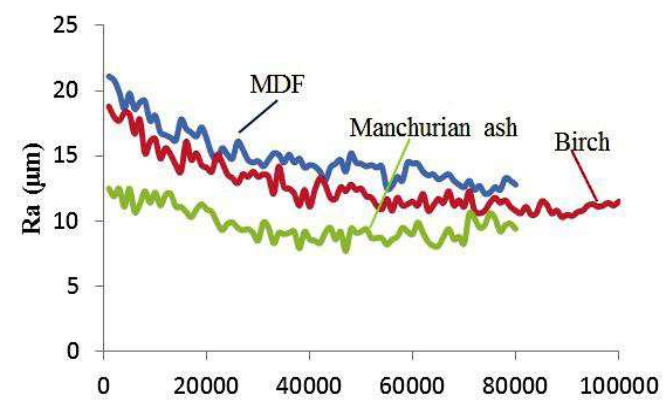

Gambar 4. Perbandingan kekasaran bahan keras dan lunak

(Taylor dkk., 1999)

\subsection{Ampelas}

Tujuan proses pengampelasan ini adalah berfungsi untuk menghaluskan permukaan bahan dengan cara digosokkan dengan amplas. Tingkat kehalusan dan kekasaran permukaan amplas pada umumnya ditunjukkan dengan angka yang tercantum dibalik ampelas tersebut. Semakin besar angka yang tertulis menunjukkan semakin halus dan rapat susunan pasir amplas tersebut. Terdapat dua jenis material abrasif amplas yang umum digunakan pada pekerjaan perbaikan dan penyelesaian bodi otomotif, yaitu silicon carbide dan alumunium oxide.

- Partikel abrasif yang terbuat dari silicon carbide, terpecah-pecah menjadi butiran kecil pada saat pengamplasan dan secara konstan memunculkan sisi baru yang tajam. Partikel-partikel ini sangat sesuai untuk mengampelas (sanding) cat yang relatif lunak.
- Oxidized alumunium merupakan partikel abrasif yang sangat kuat dan tahan aus. Oleh karena itu oxidized alumunium sangat sesuai digunakan untuk mengampelas cat yang relatif keras.

- Ampelas berfungsi untuk menghaluskan permukaan dengan cara digosokkan, halus dan kasarnya kertas ampelas ditunjukkan oleh angka yang tercantum dibalik kertas ampelas tersebut. Semakin besar angka yang tertulis menunjukkan semakin halus dan rapat susunan pasir ampelas tersebut. Ampelas digunakan untuk mengampelas lapisan cat, putty (dempul) atau surfacer.

- Pada pekerjaan perbaikan dan penyelesaian bodi otomotif, ampelas digunakan untuk menggosok lapisan cat, dempul, atau surfacer.

- Ampelas merupakan salah satu jenis material abrasif yang dibuat dengan proses perlekatan (coated abrasive). Ampelas terdiri atas dua bagian yang disatukan, yaitu material abrasif dan material backing. Material backing yang digunakan pada ampelas merupakan bahan fleksibel, terbuat dari kertas, kertas tahan air, kain, dan synthetic fiberglass.

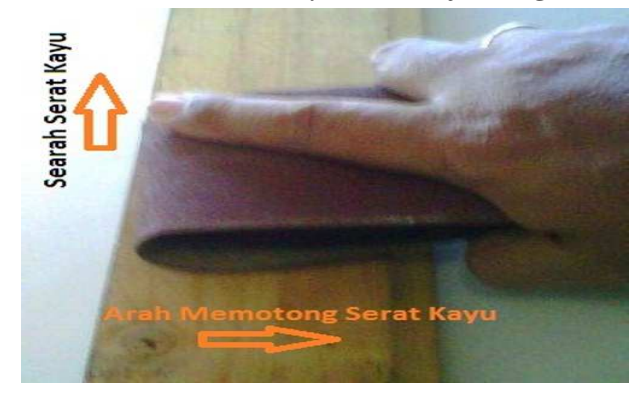

Gambar 5. Cara pengampelasan yang benar

(Sumber:Penel. Terapan Pratama 2018)

\subsection{Kekasaran Permukaan}

Kekasaran permukaan merupakan ukuran penyimpangan halus di permukaan. Lebar, tinggi, dan bentuk penyimpangan pada permukaan menghasilkan kualitas permukaan suatu produk. Permukaan kekasaran diukur 
dengan menggunakan stylus type profilometer (Mitutoyo SJ-301). Dua parameter kekasaran yang masing-masing dicirikan oleh standar ISO 4287 (1997), ratarata kekasaran (Ra), dan tinggi puncak-kelembah (Rz) permukaan partikel. Faktor pengampelasan penting lainnya adalah ukuran pasir. Hasilnya menunjukkan bahwa penggunaan ukuran pasir yang lebih halus meningkatkan kekasaran permukaan benda uji. Penggunaan sabuk ampelas kasar menyebabkan masalah pola goresan. Salah satu solusi dari masalah ini adalah pengampelasan dengan abrasif kasar yang lebih halus (NPA 1993).........Gökay Nemli, Turgay Akbulut and Emir Zekoviç (2007). Parameter amplitudo kekasaran permukaan yang dipakai di industri ada tipe, seperti roughness average ( $\mathrm{Ra})$, root-mean-square roughness $(\mathrm{Rq})$, dan maximum peak-to-valley roughness (Ry atau Rmax). Parameter yang digunakan dalam penelitian ini adalah $\mathrm{Ra}$, karena parameter ini dianggap paling cocok untuk proses pemesinan dan lebih sensitif terhadap penyimpangan yang terjadi pada proses pemesinan. Kekasaran rata-rata (average roughness) $\mathrm{Ra}$, adalah nilai integral absolut dari tinggi profil kekasaran sepanjang pengamatan. $\mathrm{Ra}$ adalah harga rata-rata aritmetik dibagi harga absolutnya jarak antara profil terukur dengan profil tengah dirumuskan sebagai berikut :

$$
R_{a}=\frac{1}{L} \int_{0}^{L}|y(x)| d x \mu \mathrm{m}
$$

Keterangan :

$\mathrm{Ra}=$ simpangan rerata perhitungan dari rata-rata garis

$\mathrm{L}$ = panjangnya sampling

$\mathrm{y}=$ ordinat kurva profil

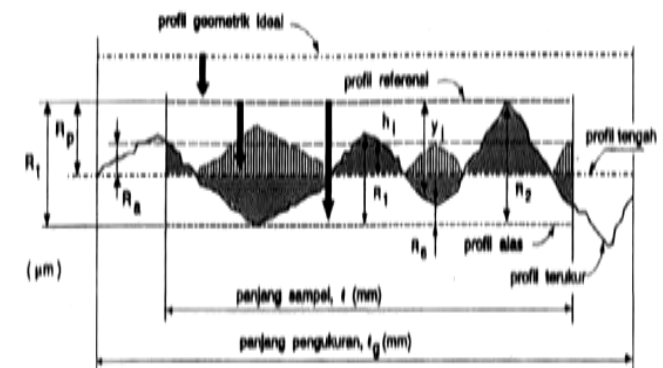

Gambar 6. Profil kekasaran permukaan (Rochim, Taufiq, 2001)

\section{Metode Penelitian}

\subsection{Bahan Penelitian}

Bahan penelitian yang digunakan adalah berupa : Aluminium cor, kayu jati, dan kayu mahoni.

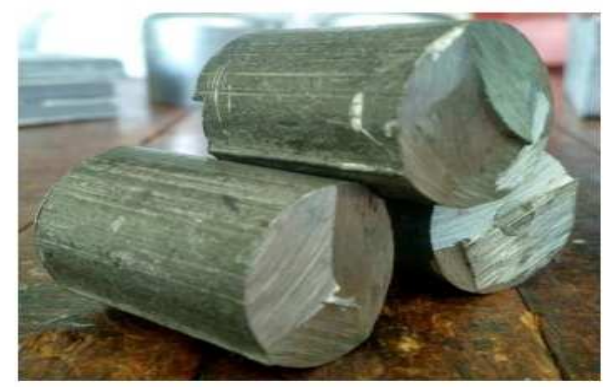

Gambar 7. Aluminium cor

(Sumber:Penel. Terapan Pratama 2018)

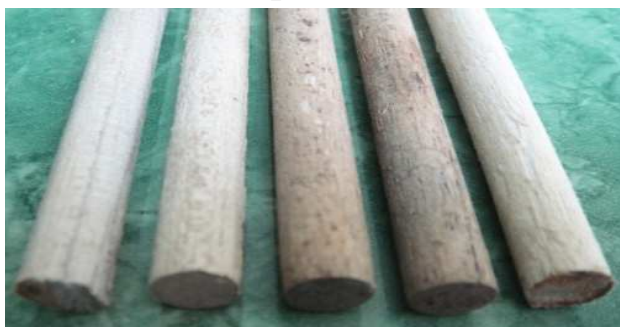

Gambar 8. Kayu jati dan mahoni

(Sumber:Penel. Terapan Pratama 2018)

\subsection{Peralatan Penelitian}

Peralatan penelitian yang digunakan adalah mesin ampelas sabuk (Belt Sanders) dan alat uji kekasaraan. Mesin ampelas sabuk digunakan untuk mengampelas spesimen, sedangkan alat uji kekasaran digunakan untuk mengukur kekasaran permukaan spesimen. 


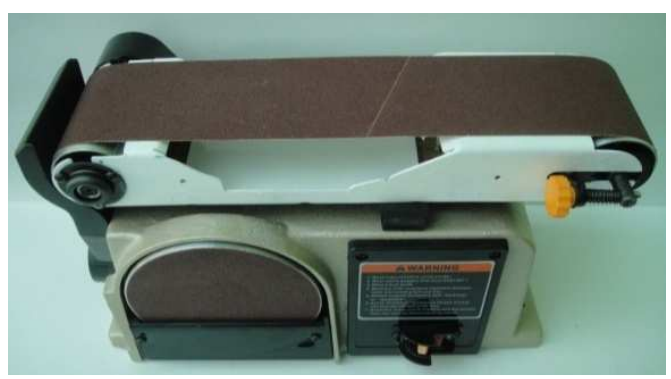

Gambar 9. Mesin ampelas sabuk

(Belt Sanders)

(Sumber:Penel. Terapan Pratama 2018)

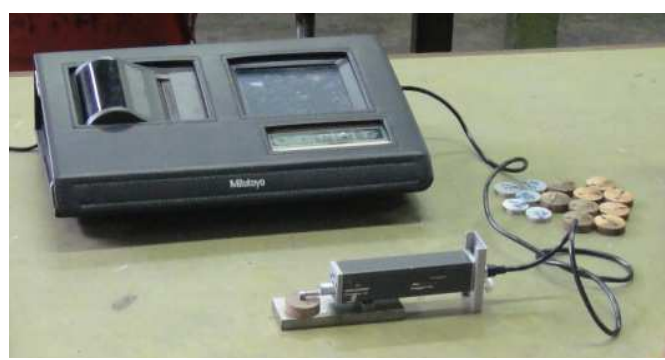

Gambar 10. Alat uji kekasaran

(Sumber:Penel. Terapan Pratama 2018)

\subsection{Variabel Penelitian}

Variabel yang dilakukan pada penelitian ini adalah kekasaran ampelas yaitu : 60, 100, 150, 180, dan 240 .

\subsection{Langkah Percobaan}

Langkah-langkah percobaan yang dilakukan pada penelitian ini adalah sebagai berikut :

a. Potong-potong bahan aluminium cor, kayu jati, dan mahoni ukuran $\phi 30 \mathrm{~mm} \mathrm{x}$ $10 \mathrm{~mm}$ masing-masing sebanyak 15 buah, sebagai bahan uji (spesimen).

b. Tandai spesimen dengan spidol sesuai dengan nomer urut spesimen.

c. Pasang kain ampelas no. 60 pada Belt Sanders.

d. Hidupkan Belt Sanders dengan menekan tombol "ON".

e. Ampelas salah satu permukaan spesimen dari bahan aluminium cor kayu jati, dan kayu mahoni dengan menggunakan Belt Sanders. f. Ukur kekasaran masing-masing permukaan spesimen dengan menggunakan alat uji kekasaran.

g. Ganti ampelas no. : 100, 150, 180, dan 240.

h. Lakukan proses pengampelasan pada seluruh spesimen.

i. Ukur kekasaran permukaan seluruh spesimen.

j. Matikan Belt Sanders dengan menekan tombol "OFF".

k. Lakukan analisa data dari semua hasil pengujian kekasaran spesimen.

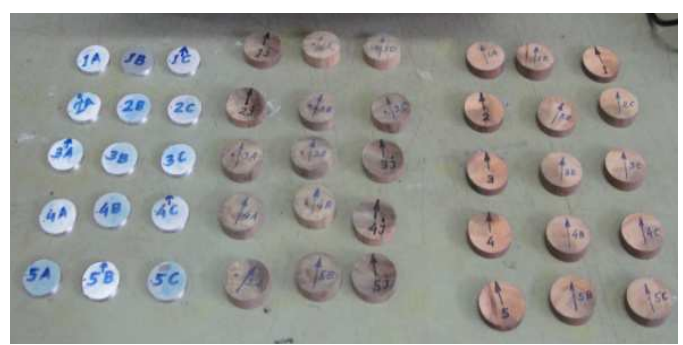

Gambar 11. Spesimen uji kekasaran

(Sumber:Penel. Terapan Pratama 2018)

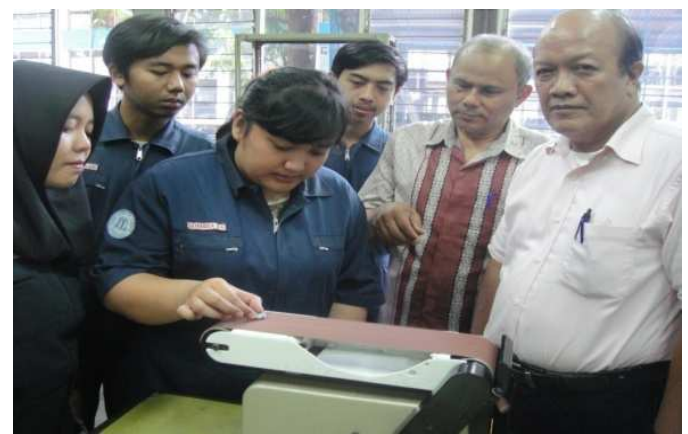

Gambar 12. Pengampelasan aluminium (Sumber:Penel. Terapan Pratama 2018)

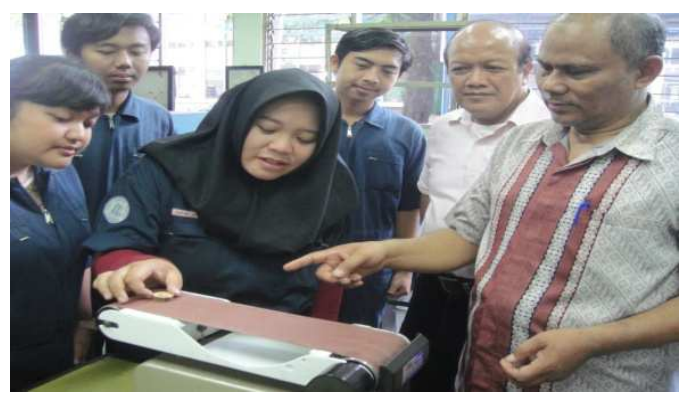

Gambar 13. Pengampelasan kayu jati (Sumber:Penel. Terapan Pratama 2018) 


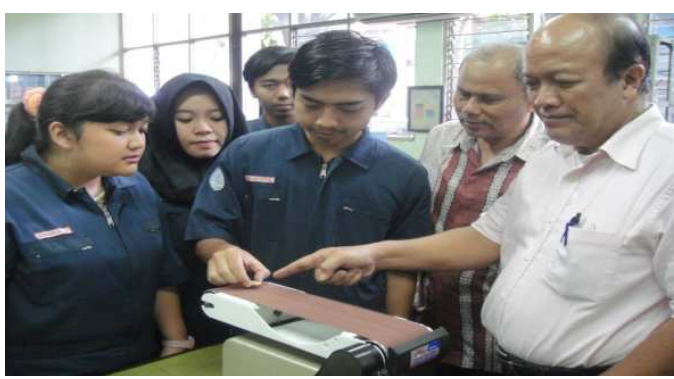

Gambar 14.Pengampelasan kayu mahoni (Sumber:Penel. Terapan Pratama 2018)

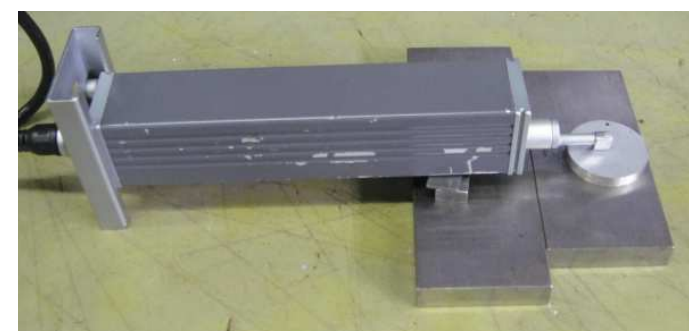

Gambar 15.Pengujian bahan alum. cor (Sumber:Penel. Terapan Pratama 2018)

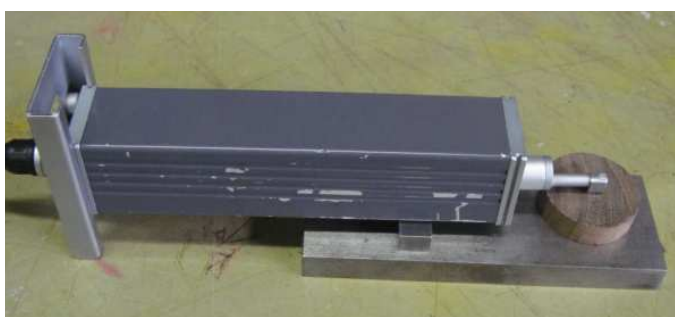

Gambar 16. Pengujian bahan kayu jati (Sumber:Penel. Terapan Pratama 2018)

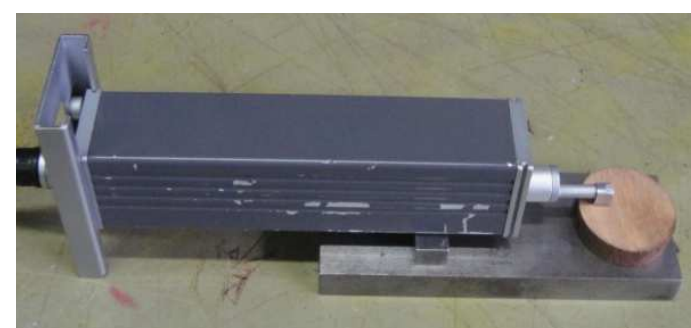

Gambar17.Pengujian bahan kayu mahoni (Sumber:Penel. Terapan Pratama 2018)

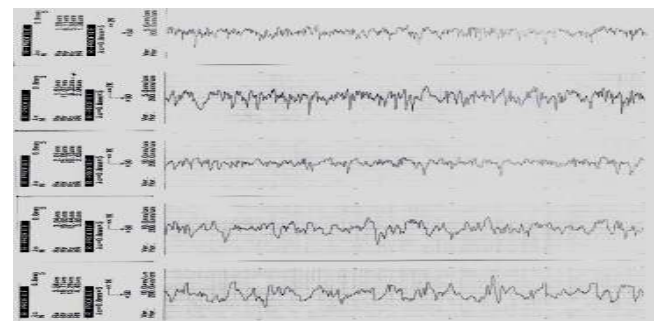

Gambar 18. Profil kekasaran bahan (Sumber:Penel. Terapan Pratama 2018)

\section{Hasil dan Pembahasan}

\subsection{Hasil Penelitian}

Dari pengujian kekasaran permukaan selanjutnya diperoleh data-data seperti pada Tabel 1, Tabel 2, dan Tabel 3 di bawah ini.

Tabel 1. Hasil pengujian kekasaran permukaan bahan coran aluminium

\begin{tabular}{|c|c|c|c|c|c|}
\hline No. & $\begin{array}{c}\text { Kekasaran } \\
\text { Ampelas }\end{array}$ & \multicolumn{3}{|c|}{ Kekasaran bahan, $\boldsymbol{\mu m}$} & $\begin{array}{c}\text { Kekasaran } \\
\text { Rata-Rata, } \boldsymbol{\mu m}\end{array}$ \\
\hline 1 & 60 & 3,46 & 3,58 & 3,53 & 3,52 \\
\hline 2 & 100 & 3,04 & 3,08 & 3,11 & 3,07 \\
\hline 3 & 160 & 2,12 & 2,08 & 2,01 & 2,07 \\
\hline 4 & 180 & 1,61 & 1,54 & 1,63 & 1,59 \\
\hline 5 & 240 & 1,11 & 1,07 & 1,09 & 1,09 \\
\hline
\end{tabular}

(Sumber:Penel. Terapan Pratama 2018)

Tabel 2. Hasil pengujian kekasaran permukaan bahan kayu jati

\begin{tabular}{|c|c|c|c|c|c|}
\hline No. & $\begin{array}{c}\text { Kekasaran } \\
\text { Ampelas }\end{array}$ & \multicolumn{3}{|c|}{ Kekasaran bahan, $\boldsymbol{\mu m}$} & $\begin{array}{c}\text { Kekasaran } \\
\text { Rata-Rata, } \boldsymbol{\mu m}\end{array}$ \\
\hline 1 & 60 & 10,32 & 10,01 & 10,27 & 10,20 \\
\hline 2 & 100 & 6,77 & 6,94 & 6,89 & 6,87 \\
\hline 3 & 160 & 4,78 & 4,99 & 4,95 & 4,90 \\
\hline 4 & 180 & 4,57 & 4,43 & 4,62 & 4,54 \\
\hline 5 & 240 & 3,61 & 3,67 & 3,72 & 3,67 \\
\hline
\end{tabular}

(Sumber:Penel. Terapan Pratama 2018)

Tabel 3. Hasil pengujian kekasaran permukaan bahan kayu mahoni

\begin{tabular}{|c|c|c|c|c|c|}
\hline No. & $\begin{array}{c}\text { Kekasaran } \\
\text { Ampelas }\end{array}$ & \multicolumn{3}{|c|}{ Kekasaran bahan, $\boldsymbol{\mu m}$} & $\begin{array}{c}\text { Kekasaran } \\
\text { Rata-Rata, } \boldsymbol{\mu m}\end{array}$ \\
\hline 1 & 60 & 10,78 & 10,64 & 10,69 & 10,70 \\
\hline 2 & 100 & 7,12 & 7,07 & 7,21 & 7,13 \\
\hline 3 & 160 & 6,09 & 6,11 & 6,02 & 6,07 \\
\hline 4 & 180 & 3,87 & 3,95 & 3,90 & 3,91 \\
\hline 5 & 240 & 3,48 & 3,41 & 3,53 & 3,47 \\
\hline
\end{tabular}

(Sumber:Penel. Terapan Pratama 2018)

Dari Tabel 1, 2, dan 3 di atas selanjutnya diplot dalam bentuk grafik seperti pada Gambar 19 di bawah ini.

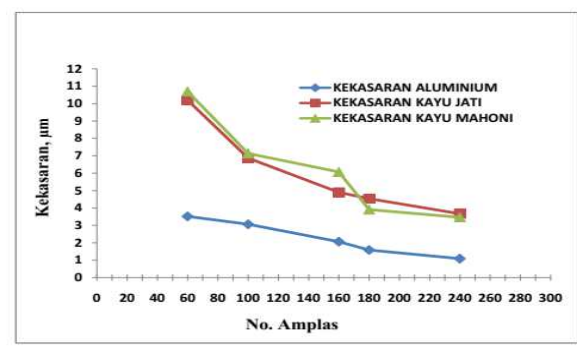

Gambar 19.Pengaruh kekasaran ampelas terhadap kekasaran bahan

(Sumber:Penel. Terapan Pratama 2018) 


\subsection{Pembahasan Penelitian}

Dari Tabel 1 pada bahan coran aluminium dapat dilihat bahwa semakin tinggi nomor ampelas, semakin halus permukaan bahan. Dengan menggunakan nomor ampelas 60 rata-rata kekasaran permukaan bahan yang terjadi adalah 3,52 $\mu \mathrm{m}$, sedangkan dengan menggunakan nomor ampelas 240 rata-rata kekasaran permukaan bahan yang terjadi adalah 1,09 $\mu \mathrm{m}$. Pada Tabel 2 pada bahan kayu jati dapat dilihat bahwa dengan menggunakan nomor ampelas 60 rata-rata kekasaran permukaan bahan yang terjadi adalah 10,20 $\mu \mathrm{m}$, sedangkan dengan menggunakan nomor ampelas 240 rata-rata kekasaran permukaan bahan yang terjadi adalah 3,67 $\mu \mathrm{m}$. Sedangkan Pada Tabel 3 pada bahan kayu mahoni dapat dilihat bahwa dengan menggunakan nomor ampelas 60 rata-rata kekasaran permukaan bahan yang terjadi adalah 10,70 $\mu \mathrm{m}$, sedangkan dengan menggunakan nomor ampelas 240 rata-rata kekasaran permukaan bahan yang terjadi adalah 3,47 $\mu \mathrm{m}$. Hasil penelitian ini sesuai dengan hasil-hasil penelitian beberapa peneliti sebelumnya. Taylor dkk. (1999) mempelajari hubungan antara variabel input dan tingkat removal material, kekasaran permukaan. Berkenaan dengan ukuran pasir kasar dan semua spesies, silikon karbida menghasilkan permukaan yang lebih baik daripada aluminium oksida. Menurut Magoss dan Sitkei (2001), kualitas permukaan akan dipengaruhi oleh beberapa faktor baik dari sifat bahan maupun proses permesinan. Sifat bahan meliputi butiran, kerapatan, kadar air dan lainnya. Menurut Saloni dkk. (2005), tingkat pelepasan material dapat berubah dengan variasi tekanan, tipe abrasif, granularitas dan kecepatan pengamplasan. Dalam kebanyakan kasus, kecepatan pengamplasan yang lebih tinggi bisa menghasilkan permukaan yang lebih baik. de Moura dkk. (2011), menunjukkan variasi kekasaran permukaan bahan yang diampelas dengan Sabuk abrasif grit 60 dan 100, baik dalam arah longitudinal dan melintang. Dapat dicatat bahwa kekasaran permukaan pengampelasan longitudinal lebih tinggi daripada pengampelasan melintang. Mereka menegaskan bahwa kekasaran permukaan jelas lebih tinggi secara tegak lurus ke arah penggerak sabuk abrasif dari pada sejajar. Masing-masing butir akan memberikan kedalaman yang lebih kecil, sehingga menghasilkan hasil akhir yang lebih baik.

\section{Kesimpulan dan Saran}

\subsection{Kesimpulan}

Kesimpulan yang diperoleh dari penelitian ini adalah :

a. Semakin tinggi nomor ampelas semakin halus permukaan bahan.

c. Kekasaran (Ra) permukaan bahan hasil pengampelasan produk UKM lebih tinggi daripada pengampelasan dengan menggunakan mesin pengampelas sabuk.

\subsection{Saran}

Beberapa saran yang perlu disampaikan di dalam penelitian ini adalah sebagai berikut :

a. Untuk menghasilkan data-data yang lebih valid maka perlu ditambahkan beberapa parameter pengampelasan, seperti kecepatan dan tekanan pengampelasan.

b. Untuk bahan kayu sebaiknya menggunakan alat uji kekasaran khusus bahan-bahan lunak.

\section{Daftar Pustaka}

- ASM Handbook, 1992, Mechanical Testing and Evaluation, Volume 8, ASM International.

- Aguilera, A., 2011: Cutting energy and surface roughness in medium density fiberboard rip sawing. Eur. J. Wood Prod. 69(1): 11-18. 
- De Moura, L.F.; Brito, J.O.; Nolasco, A.M.; Uliana, L.R. 2011. Effect of thermal rectification on machinability of Eucalyptus grandis and Pinus caribaea var. hondurensis woods. European Journal of Wood and Wood Products 69(4):641-648.

- Harmanto, S., 2016, Pengaruh Temperatur Cetakan Logam Terhadap Kekerasan Pada Bahan Aluminium Bekas, Jurnal Rekayasa Mesin ISSN 1411-6863 Volume 11 Nomor 2, Agustus 2016 Polines, Semarang.

- Magoss, E., Sitkei, G., 2001: Fundamental relationship of wood surface roughness at milling operations. In: $2^{\text {nd }}$ International Wood Machining Seminar 15, 2001, Anaheim.

- Marsoem SN. 2013. Studi mutu kayu jati di hutan rakyat Gunungkidul. I. Pengukuran laju pertumbuhan. Jurnal Ilmu Kehutanan 7, 108-122.

- Nemli, G. \& Çolakoglu, G. 2005. The influence of lamination technique on the properties of particleboard. Building and Environment 40(1): 83-87.

- Rochim, Taufiq, 2001, Spesifikasi Metrologi danKontrol Kualitas Geometrik. Laboratorium Teknik Produksi dan Metrologi Industri.
- Saloni, D.E., 2007: Process monitoring and control system design, evaluation and implementation of abrasive machining processes. Thesis (Ph.D.). North Carolina State University, Raleigh, 197 pp.

- Sulistyo J \& Marsoem SN. 2000. Pengaruh umur terhadap sifat fisika dan mekanika kayu jati (Tectona grandis L.f). Prosiding Seminar Nasional II MAPEKI. Yogyakarta, 2-3 September 1999. 49-63.

- Taylor, J.B., Carrano, A.L., Lemaster, R.L., 1999: Quantification of process parameters in a wood sanding operation.Forest Products Journal 49(5):41-46.

- Wahyudi I \& Arifien AF. 2005. Perbandingan struktur anatomis, sifat fisis, dan sifat mekanis kayu jati unggul dan kayu jati konvensional. Jurnal Ilmu \& Teknologi Kayu Tropis 3(2), 9-15.

- Yunianti AD, Wahyudi I, Siregar IZ, \& Pari G. 2011. Kualitas kayu jati klon dengan jarak tanam yang berbeda. Jurnal Ilmu \& Teknologi Kayu Tropis 9(1), 93-100. 